SHS Web of Conferences 23, 01001 (2016)

DOI: $10.1051 /$ shsconf/ 20162301001

(C) Owned by the authors, published by EDP Sciences, 2016

\title{
The Problems of Socio-Cultural Community in Patani and Penang: A Comparative Study
}

\author{
Aminoh Jehwae \\ School of Humanities \\ University Sains Malaysia \\ (ayasalae@hotmail.com) \\ and \\ Assot. Prof. Dr. Siti Hajar Che Man \\ School of Humanities \\ University Sains Malaysia \\ (shajar@usm.my)
}

\begin{abstract}
There are different socio-cultural in a society. Socio-cultural is a lifestyle and civilization for some society, born from the grip and tendency of community member in various fields of life, to give satisfaction and stimulate the development of community life. Diversity of perception and socio-cultural is one of the stem that led to the conflict. This is one convention that is already known to the public equally there is a conflict with humans or nature. Everything is becoming common place of human life. But what is true in a society has received attention by the authors in exposing matters of human problems or crisis faced by the community. In this paper we will discuss the problem of socio-cultural force in Patani and Penang society in Montri Sriyong's novel and Azmi Iskandar Merican's novel. To discuss this problem, two novels from Thailand and Malaysia was chosen as the corpus of analysis, namely Rusni (2012) and Aci Patmabi (2012) by Azmi Iskandar Merican. Montri Sriyong is the winner of SEA WRITE AWARD in 2007 and Azmi Iskandar Merican is a new comer writer who has colored the world of creative writing in Malaysia. Both novels express Malay socio- cultural community. Various problems and chaos that has prevailed in the society so as to bring the various conflicts faced by people who are forced together in Patani and Penang. Scope of this paper will examine whether the causes that give rise to stem the outbreak of Malay socio-cultural communities in Patani and Penang. Cultural studies theory used as a platform to study these novels. The theory of cultural studies that serve as the foundation lead to cultural element in the form of literary works, as there are cultural objects, ways of life and beliefs. Acquired discussion will serve as a reference to show the reality of life truth Patani and Penang society as proposed by both the author.
\end{abstract}

Keyword: socio-cultural, Patani, Penang, novel, cultural studies, ideology 


\section{SHS Web of Conferences}

\section{Introduction}

Novel is a genre of prose literary form that displays human life which is very similar to the nature of reality. Literature is imitation [mimetic], although in reality the meaning of reproduction [credo], but realism remains a key prerequisite of all claims and fiction. In fact every artist conscious element of realism in his work. Novel is a literary work that tells a story which is very similar to the human nature of reality. According to Shannon Ahmad (1980:4), "the novel is a form of interpretation of the composition of human life through a form, which is fiction. It is a summary of the three main factors that lead- offset between each other, which is a personal experience, the reality of life and imaginative compositions and ideas are generated from these three factors, swirling in one thing". Because novel is not just a story, but in it quoted historical, cultural, political, philosophical, ideological, civilizational and others, blended with imagination and fantasy author. But novel is one of the genres that interest the reader in understanding the life of a community. This is because the novel has become a voice for the community. High literary value can change a reader worldview ideologically, philosophy of life, patterns of thought and behavior in a positive direction.

According to Edward Said (2009: 84), the novel is a kind of culture that integrate and half total. Compact it is a highly regulated plot mechanism and overall social referral system that relies on existing institutions in bourgeois society, authority and power. Therefore, this paper tries to explore the socio-cultural problems occur for the Malays in Patani and Penang through Rusni (2012) by Montri Sriyong and Aci Patmabi (2012) by Azmi Iskandar Merican. The scope of this paper will examine the socio-cultural problems that occur in both communities either Patani or Penang and dig up the root causes of the problem in such a way. The theory of cultural studies as a platform to study with a focus on the concept of ideology. In the context of this discussion, Patani refer to the resident population in Thailand 's three southern border provinces, Narathiwat, Pattani and Yala. Penang was referring to the Malay population in Tanjung, Penang, Malaysia.

Basically, this study will use the theory of cultural studies in the analysis of text study using the principles put forth by Chris Barker. Theoretical study of culture is very suitable theory in literary study that examines the socio-cultural aspects of a society. This is because the theory is used among anthropologists and sociologists to study and understand the culture of a society. In fact, this theory is said to have been born in the social science disciplines and partly consider this discipline has reached the grand narrative (Mana Sikana 2007: 421). However, in the literature, it is a literary theory, as well as the theory of literary criticism. Without denying that some think tank is derived from the disciplines of anthropology and sociology.

This theory has a position and influence as described by Lawrence Grossberg (1993:21) that:

Cultural studies is becoming one of the most ambiguous terms in contemporary theory as it is increasingly used to refer to entire range and diversity of what had been previously thought of as critical theory (i. e a range of competing theories of the relation of society and 
culture, of ideology and art, largely derived from 'high literary theory, and anthropology, with communication and popular culture once again relegated to a secondary position.

This is because the theory of cultural studies encompass all areas whether in relation to society and culture, ideology and art, anthropology, communications and popular culture. But this theory can lead the reader to see the relationship between the text, the author and the reader with the social, political, economic, linguistic and religious and artistic result of a reflection on the reading of literary texts. In the same context, see the aspects related to individual development and its role in the formation of society.

In dealing with social and cultural issues affecting the nature of the Patani Malays, the concept of ideology will be the centerpiece of the discussion. The question of ideology is a matter that can not be ruled out. Ben Agger ( 1992: 232 ) cites the views of Marx and Eagles are expressed in cultural criticism, ideology is the ideology influence of the ruling class. This view depends on the shape and mood of society.

Ideology is derived from the Greek word meaning the idea of ideas and logos meaning knowledge. Kamus Dewan, Third Edition (1998: 476 ), gives the meaning of beliefs (doctrine) that is worn or the ambition of a policy rule. Longman Encyclopedia (1987) defines ideology as "System of ideas, or a particular class or group and serving to rationalize their interest".

According to Chris Barker (2003: 77), for Althusser, ideology is one of the three primary instances or levels of a social formation. As such, it is relatively autonomous from other levels (e.g. the economic), through it is determined by it 'in the last instance'. Here ideology, 'a system (with its own logic and rigour) of representations (images, myths, ideas or concepts)'. There are four aspects of Althusser's work which are core to his view of ideology:

1) ideology has the general function of constituting subjects.

2) Ideology as lived experience is not false.

3) Ideology as misrecognition of the real conditions of existence is false.

4) Ideology is involved in the reproduction of social formation and their relations of power.

However, according to James H. Kavanagh ( $1991: 181$ ),

Ideology is a social process that works on and through (every social subject (every individual, every member of a social group) that, like every social process, everyone is 'in', whether or not they 'know' or understand it. It has the function of producing an obvious reality that social subjects can assume and accept, precisely as if it had not been socially proceed (through system of representation) and did not need to be 'know' at all. 
This means that the ideology of building social relationships and every social entity is experiencing a social process involving the participation of whether they understand or not. In the eyes of government, ideology, including a set of ideas that become important as an inspirational symbol of the power of a group such as the government to meet its political interests. For example, in Thailand the basis of the formation of the nation-state is a set of ideas that are built to form single race country, namely the Thai nation. Although Thailand has a variety of races and ethnicities, but the government will still hold an ideology that unity would exist if the country has one nation, one culture and one relegion. This is in contrast with the atmosphere and the phenomenon in Malaysia.

\section{(i) background created novel Rusni}

Rusni have been produced by Montri Sriyong in 2012. After eight years of the outbreak of renewed conflicts in the South of Thailand. Montri Sriyong is a young writer who comes from the region of Songkhla. He got a boon SEA Write Award in 2007 in a portion of poetry. He also produced many works that touch the Malay culture and society such as poetry, short stories and novels. But the more he produces poetry than other genres. The poetry which won the SEA Write Award namely, Lok Nai Duangta Khabjao (2007). Rusni is also shortlist to grace the SEA Write Award in 2012. One could say that this novel is a beam of life of the Malays in Southern Thailand, especially the issue of the unrest that occurred in three provinces in southern Thailand that was mentioned by Sataporn Srisajjang that the novel is actually the person who is responsible for resolving the conflict in southern Thailand must read especially Yinglak Chinawatra, Prime Minister Thai as well as ministers.

This novel describe the background of conflict in Southern Thailand Malay village Khaelek, Bachok district, Narathiwat province around the year 2000. The story is presented through the character "Rusni" a girl who is suffering. After her parents died of shot, she lived alone in the village Khaelek full of hardship, pain and fear. However Rusni had to face with the gritty soul. Not only Rusni that confronted this life, there are still some young people have a way of life that is not much difference with Rusni. Among them is Yahya, a compatriot Rusni. He also lost their parents and relatives. His parents were also shot on the way back from Bachok hospital. Even Yahya is also accused of being one of the fighters in the liberation of Patani. Yahya dismissed accusations from people in the village Khaelek until he decided to find a new life on the Budo hill because he think Budo hill still want him. He was willing to live alone on a hill than staying in the village full of accusations and insults. Similarly, "Suhaiming", a teenager from Yala province. He suffered a disability due to polio since childhood. He also lost their parents in the wake of the conflict in Southern Thailand. His parents were killed by a group of freedom fighters who are trying to make Suhaiming as a tool for their cause. But eventually Suhaiming had migrated to Hadyai to stay away from being pulled into the group of fighters. Rusni when Yahya fled to the hill of Budo, she decided to move to Hadyai with her father's freind. There she meet with Suhaiming. However, their introduction has caused serious injury to Rusni. Rusni raped by Adun, the son

of her father's freind. Eventually she escaped from Adun and choose to stay home with the Thais. But life does not end with happiness. She was shot by Adun at the end. 
This novel is actually trying to describe the situation in Southern Thailand by making the characters as the focal child as Rusni, Yahya, Suhaiming and Adun. These four characters are facing the same pressures of life except Adun. But basically the author is trying to give the impression to the public that the conflict in Southern Thailand has left deep wounds on community members especially children. Terrorism has destroyed human life regardless of age and gender. Children lost their father. Many women who become single mothers because her husband was killed or captured. There are also gone missing. This is what happened in Southern Thailand today. Various problems faced by the residents of the area. This is because the Southern Thailand is a distinct region with other regions in Thailand both in terms of language, religion and culture. Residents of the vast majority of Malay Muslims, with more than 80 percent and a way of life that is based on Malay culture. They use the Malay language in their daily lives (Office for National Statistics, 2014). Therefore, no wonder if the area is said to be a unique area.

\section{Rusni: The Problem of Socio-Cultural Community in Patani}

Rusni novel analysis found that the two ideological elements found in the novel. First, ideology formed by the Thai government is focusing on the concept single race. Thus, there is some basis for ongoing in Southern Thailand as integration policy, the policy of assimilation and Thai policy Rattaniyom. The policy was seeping into the soul of the Thai government, especially government officials who assume identities held by the Malays in Southern Thailand to be the root cause of a dispute between citizens and government. As for the Malays the ideology is formed on the basis of Islam and Malay culture. Islam is the way of life of the Malays here. Therefore, the government needs to understand the ideology of Malay depth. So it does not create a conflict between the two sides.

Thus, ideology plays an important role in shaping unity. Various ideological differences have caused the problem. Often the authorities try to influence the lower classes. They will try to eliminate the ideology of the peasants. But the Malays in Southern Thailand is not that simple. Ideology in preserving cultural identity, religion and language as powerful as alleged by Imtiyaz Yusuf (2006: 175),

It is a matter of facts that the Malay Muslim place strong emphasis on ethic aspect of their adherence to the relegion of Islam. The Malay Muslim of the South give primacy to their ethnic identity and view their life experience from within the context of the local practice of Islam thus the ritual, mythic/narraive, experiential/emotional, ethical and legal, social, material and political aspect of life are interpreted and perceived through the lenses of ethnic identity. Here ethnicity and relegion are intermixed with each other, with relegion being perceived in ethnic perspective. 
The diversity of cultures, religions, languages are often said to be the root causes of conflict. Thai government should have acknowledged that peace can exist in a twist (Unity of Diversity) because it is the only step that is carried out in countries of conflict.

This novel has been shown that the unrest in southern Thailand has triggered a socio-cultural problems both in terms of economy, education, politics, drug addiction, immorality, community relations, orphans and others. Ideological differences among the factors that create a variety of problems. This is because Thailand has a diversity of religions, cultures and languages. Thus, there has been a wide range of ideologies held by each group member of society. Some of the factors that shape the ideology. Among the racial/tribal, linguistic diversity, culture, religion/belief, geography, history, travel the nation, independence history, the history of birth/founding countries and finally the ambition or the hope of the nation. Factors that have influenced the ideological formation in every race. Similarly Malay in Khaelek village, Narathiwat. Rokib, Ruslan, Yahya and Wae Da -oh has formed an ideological through the glorious history of Patani. They have risen to fight to defend the sovereignty of the Kingdom of being a member of the Patani liberation fighters. However, for the Thai government, such action threatens the safety and relative security. Then triggered a variety of strategies to resolve conflicts in Khaelek village. One of them is by sending troops into Khalek village. Based on the review stages carried out by Duncan McCargo (2006: 4), the problem of violence in Southern Thailand due to the failed and contradictory policies implemented during the government of former Prime Minister Thaksin Shinawatra. While the government established the National Reconciliation Commission (NRC) in March 2005 to foster peace and reconciliation in the southern provinces, it shortly, in July 2005, declared the state of emergency in order to place the absolute decision power in the hands of the military. Obviously, it has sparked anger among members of the village because the villagers soldiers rude and compassionate nature. That is shown by the author of the novel Rusni. Many young men of the village, but women have been victims of such soldiers arrest Yahya and Rusni. Actually many Malays who accused killer though there is no proof. This is because the government has provided service to the government, especially the soldiers to remove the state of emergency in the three Southern border provinces of Thailand. Thus, many also have a goat in this case.

When the villagers were more caught, then there are some families who are not brave enough to go anywhere although this batch in the afternoon. Therefore, many have stopped working as rubber tapping, especially on a hill far away from the house. This is because there are some famous people Khaelek villages that have been shot or arrested while tapping rubber. Some are lost. Events have an adverse effect on the Khaelek village whether the lack of income and security is not guaranteed.

The problem of poverty among the Malays is a problem that has long appeared. Though many projects already undertaken by the government in eradicating the problem. Khaelek population still live in poverty and difficult. They work tapping rubber trees and plant rice. Poverty is the author described, "... She is only child. Her parent are farmer that took over many generations. As the home of her resentment almost every household. Budo hill foothills 
surrounding villages tribulations. (p.17). Poverty has been understood by the villagers that it stems from the government's dishonesty in solving poverty as described by a character in the novel, "...He inquired as to the economic status of Wae Da-oh, the poor as well as others. He explained that all of that is because of the neglect of the state, never care for the well being of all Muslims. Besides government officials themselves vile acts against Muslims as a nonperson. He pointed out the arrests cast. The suspect disappeared without a trace his foot to Somchai Neelapaijit kidnapped disappearances stay silent" (p. 48). In addition to poverty, the Malays also facing invasion of human rights such as making an arrest without a warrant of arrest had happened to John and Rusni. Government officials have to take Yahya and Rusni suspect to the police station because both fighters have joined the liberation of Patani. This has left deep wounds on Rusni and Yahya, because they are still kids. It definitely cuts that will haunt their lives. Rusni and Yahya are victims of violence. All the villagers Khaelek faced with violence until the end of the village there are no inhabitants. Many have migrated to other places. Some are going to Hadyai and some have moved to Malaysia. The reason is simply to find shelter. They want security and peace. This situation occurred in the Southern region of Thailand. No one dared to live longer in their own homes, especially the youth .

In addition, government officials often dim view of the Malays until they are forced to stay away from society. Their lives are not directed. That happened to Yahya. While he was still a child, but a government official who considers himself to be unreliable. Allegations by accusations leveled at Yahya without checking. Finally Yahya choose the path easily by entering the Patani liberation in Bukit Budo. It has destroyed the life of a man just because of different ideologies. The government has a strong ideological defend Thailand with one race, one religion and one culture. Whereas John adheres to stand as the Malays who should defend Islam and Malay identity

Here there is fire, there is a bomb. School burned. Hut is said to be a place to educate young people to be fighters. Religious teachers accused of being terrorists and drug dealers. Reciprocal prejudice to each other. They do not believe. Khaelek villagers live with caution. This is what causes many of the villagers move out. More so when the soldiers in the village, the villagers do not feel safe. This is because the soldiers have a bad impression of the Malays. They have an ideology contrary to the villagers. It can be seen in the quote, "He does not trust Muslims. They are usually eradicated throughout the world suffered for want of a pure Islamic state their aim is to create the world 's Muslims concentrate Lieutenant Somsak roaring chuckle in his throat, I go for that. This way there is so decisive to flock to AlKaidah, he was not afraid, Thailand is a Buddhist, he roared loudly in a Muslim does not have the trust he reviewed the history of the southern border to the rebels. Up so much"

p. 56). This passage shows that there is disagreement between the authorities and the Malays, especially in terms of history. History of the existence of the Malays in Southern Thailand still not recognized by some government officials. Still think the Malays as a passenger not Thai citizens. While Thailand has a diversity of religions, cultures and languages. That has raised many issues here. We encourage Thai people to understand and respect their identity. 
Rusni novel also illustrates the problems children lost their parents due to the violence in Southern Thailand as Rusni, Yahya and Suhaiming. They are all still children but has lost the love of riding. Cause parents to lose their life was not induced. They do not have the opportunity to learn. Therefore, the chances of getting a job are very narrow. Rusni having moved to Hadyai, she worked selling chicken at Hadyai market. Suhaiming also decided to stop studying because his uncle was killed. He did not have the support to further studies. Finally he sent the goods at the market wage. This is a problem being faced by the Malay community youth education.

Next is the problem of drugs. Drugs have become a social disease that has spread into every corner regardless of age and gender. The drug is also highlighted by the authors in this novel. Victims of drug addiction is Adun. He is Faisol son. He lived with Rusni. But his lifestyle is very different from Suhaiming though they came from three provinces in southern Thailand. This is because the Adun was raised in Hadyai. He's not get a good religious upbringing from his parents. His parents are busy with their business. Finally Adun stuck with either vices become baby pussy, taking drugs, player and loves gambling games online. He also raped Rusni because due to drug intoxication. This indicates that the drug has become destructive of human life. It could destroy everything. That happened to the Assembly when he chose drugs as her life. Eventually he killed his father, Faisol. Undermine the institution of family abuse and human civilization. They are involved with drug habits will change in terms of confidence, attitudes, values, self-respect, and even ruin the harmony in the household and community. Symptoms of addiction and drug abuse can be eradicated from the beginning if the parents monitor and educate children with love as well as watching their friends so as not to be influenced to do things against the law shrimp. When his parents were gone, he entered the Patani liberation fighter and he killed Rusni. Therefore, Rusni is very unfortunate girl. She had face various misfortunes of her life.

\section{(ii) background created novel Aci Patmabi}

Aci Patmabi is a novel work of Azmi Iskandar Merican. This novel tells the whole life, culture and history of the Malay Jawi Peranakan descent at the end of the 19th century and early 20th century. Events in this novel revolves around the setting time between 1895 and 1930. Jawi Peranakan origins are from India, Muslims and famous as traders rich and successful in Penang in the 19th century. The Jawi Peranakan were absorbed in the Malay culture and is known as the Malays, because it has a familiar equation in Muslim culture but fused as Malay culture.

Aci Patmabi is a very interesting novel tells the story of social affairs, culture, and history of the Malays in Penang. It tells the story of life in the days of Aci Patmabi women locked up at home, not allowed to go to school, waiting to get married and continue the tradition of women as subject to men in patriarchal cultures are closed. However, Aci Patmabi rise to a new awareness of the reading result of the writings of young people mainly Syed Sheikh Al Hadi, to back out of a tradition of women not only Malays but also Muslims filled 
superstitious belief back then. The struggle and the journey of life Aci Patmabi these are the driving force of the whole story of this novel.

\section{Aci Patmabi: The Problem of Socio- Cultural Community in Penang}

Socio-cultural issues that are highlighted by the author in this novel so compelling. The author describes the life of Penang's very real with real life. That's because the character is drawn Aci Patmabi as a woman who has a life story full of joy and sorrow that ultimately turned off by the author on the greed of the two sons.

This novel tells the socio-cultural turmoil Malay community in Penang around 1920 s to 1930s. Socio-cultural problems described by the authors through the action of the Malays sell the land and all property to foreigners. Action is considered the honor into the hands of other nations. It can be seen through the character Pakwan, Aci Patmabi husband who comes from a wealthy and respectable family. But forget Pakwan nature has destroyed his life and his family. Scarum nature, forget the goal of life, dignity forget, forget self, and forget everything else has been practiced by the Malays for a time before, especially the rich, who strayed from the true path of life. According Jelani Harun (2013, 211), a feature wealthy Pakwan the " cultural deficit ", which is the default and complacent pampering desires to pawn the property to a stranger. One by one his wealth is spent solely for the satisfaction of his desires. This is because Pakwan so lax in their faith to be stuck with sweepstakes, spirits and riotous with women. He became a trader who loves doing evil. The club was originally rooted Darul Falah Islamic charity and has substituted a club gambling addiction. Business inta diamond neglected perish eventually disintegrate. Than have the legal chariot, Pakwan now only own a cow. He was finally beaten by the residents of a dilapidated mosque built by his own grandfather.

In that era (1920s to 1930 s) until the early years of independence, the people of Penang bounded and dragged by the rapid economic progress. This has an effect on the socio-cultural community in Penang especially the subordinates as Chah Lenggok and Wan Kerising. Both women have been using her intelligence to get property Pakwan. This is because life in the city of Penang is full of advancements have made them choose the way to get the comfort of living matter in any way. Similarly to the case against the two boys who inherit the trait Pakwan foolishness. They have the honor simply because he desired luxury. They have sold the estate to the foreigners for the purpose of having fun. Finally, they cheat and infirm Aci Patmabi only sell their property, the bungalow at Jalan Hatin to Naraina, a former employee of his grandfather. Negligence Pakwan provide education to the children cause the children to be violent and greedy world lives up to his own mother cheated and deceived hence intellectually misleading. This suggests that the absence of religion human deflect evil ways. Pakwan brought up in luxury, but not be exposed to religion. Her parents do not force Pakwan prayer and fasting for the whole family point of view of worship that God commanded to form a ransom paid after a person dies. Then his two sons who were raised by a pack Wan among children dance the footsteps of Pakwan. Mastan and Che Din a young 
lazy, do not want to improve themselves and kept having fun. Both sons inherited their father's attitude Pakwan.

In addition there are also fights in the family due to the property. His younger half-brothers Pakwan, Janabu and Bapu rough sought to claim the house and land Seeni Rawther at Malay Street. Janabu and Bapu eventually sell all the houses and land to the Boss Ghee Hin. Patmabi oppose the sale of land to foreigners but Aci Patmabi and Pakwan make enemies and assaulted by Jenabu and Bapu badly when they tried to stop Jenabu and Bapu burn mosque in the land. Aci Patmabi not have the support of the Malays. They were especially hostile action Aci Patmabi Malays sell land to foreigners. This is because the act was Aci Patmabi degrading Malays. Aci Patmabi adamant to defend the honor of the Malays. She could not bear to see the plight of the Malays compromised. Therefore, there is the ideological conflict between Aci Patmabi with the Malays. The Malays do not realize that they actually have been deceived by others who want to scare the Malays from the earth itself. Finally, the Malays do not have to stomp the earth. This is becoming a big problem for the Malays in Malaysia, no matter anywhere, especially in areas such as Kuala Lumpur. All land is owned by white people or the Chinese.

Yet attachment to traditional practices still practiced there remains such an understanding of the religion, the role of adolescent girls, education, freedom, customs and practices. Aci Patmabi first shock to see her father in law and her husband Pakwan not praying and fasting, obligatory practices ain not even considered in this rich family, but they are more likely to waste his money to charity, pay zakat, and hold a ceremony to show their wealth. Wealth has obscured points Seeni Rawther and Pakwan. They are disobeying God by leaving prayer and fasting. The reason is because of the very heavy workload. This action was endorsed by the mother -in-law. This is a big shock for Aci Patmabi when the track home. Various superstitious practices adopted by them. Among them is a bath in Safar, to avoid the plague. Some still believe in magic when Aci Patmabi was pregnant. Her mother-in-law hired pietist to ask the saint to save Aci Patmabi. But for Aci Patmabi such practices so contrary to Islamic faith and pay a ransom is also an act of superstition. This indicates that the Malays at that time still can not leave the superstition. They are still in a state of ignorance in terms of faith and belief. Thus, the characters appear in the novel Aci Patmabi to bring awareness to the Malays not to be stuck with the loss-making practices.

The character of Aci Patmabi still not be accepted by the Malays in Penang at that time. This is because, according to Asiah Abu Samah ( 1960:2), malay women from an early age and has been confined to the fringes and brought up and educated to become a faithful wife and loving mother. They have a limited life outside his house. But not on Aci Patmabi. Although she grew up in a Malay family, but she has a mind of modern, comfortable and very keen minded notions of progressive Islam is proclaimed by Syed Sheikh Al-Hadi through Al-Imam magazine. She wants to learn high and also a passion for learning English. Obviously, her mind gets resistance from the family because the action was against the practice of traditions practiced for generations. Although she called the "modern woman" in the eyes of society, but she still retains the character of a polite Malay women. She was wearing a suit blouse 
length of dark blue velvet. Wearing fabric sentung black brocade gold thread and close her head.

This novel convey a very interesting story, to touch and to provide awareness and adequate teaching of the Malay race. Aci Patmabi is a tragedy of the Malays who compromised not only their land but also their glory and honor due to greed, not stick to religion, education and life joyful lust. Eventually the land belongs to the Malays in Penang to be right foreigners and the glory of them destroyed.

\section{Conclusion}

Based on the two works clearly show authorship different styles of socio-cultural problems of the Malays in Patani and Penang. Both novels feature characters mutually women as the whole story. But Aci Patmabi character seems more evident if compared with Rusni character. This is because the character is instrumental in changing the mindsets and society as married life, the role of women and religion. But in the end the author has put the status of the two characters in a very suffering. Aci Patmabi employees died at home because his house was sold by her sons. Rusni was killed by her friend. Obviously, here that both the novel presents a different problem socio-cultural. To slide Aci Patmabi life story, it can be concluded that life in that era (1920s to 1930s) until the early years of independence, the people of Penang bounded and dragged by the rapid economic progress. This has an effect on the socio-cultural and political Penang. Yet attachment to traditional practices still practiced there remains such an understanding of the religion, the role of adolescent girls, education, freedom, customs and practices. Aci Patmabi has been alerted to the community about the importance of the homeland. It is not accessible to the whim because not only the earth but also compromised the rights and dignity of the Malays were compromised. Socio-cultural problems that occur in the Patani and Penang due to ideological differences are embraced by the community. Novel Rusni have shown unrest that occurred in southern Thailand has a negative impact on the socio-cultural of Patani Malays, both in terms of economy, education, politics, drug addiction, immorality, community relations, orphans and others. The author has a character Rusni as a symbol of suffering and problems. Children and women have been victims of violence in southern Thailand until there was no place for them to reside longer. Similarly, the novel Aci Patmabi, Aci Patmabi have lost everything especially her native land. However, there are differences in terms of character, Rusni described by the author as a woman who no freedom, silent, shy, and low education. Even after the era of 2000, but the image of Malay women still smelling tradition. Unlike Aci Patmabi. She is the modern Malay women who have a vision and high ideals. But in the end the character is dead at the hands of the author.

\section{References}

Agger 1992. Cultural Studies: Critical Theory. London: The Falmers Press. 
Asiah Abu Samah 1960. "Emancipation of Malay Women (1945-57)” Tesis B.A. University Malaya, Singapore.

Azmi Iskandar Merican 2012. Aci Patmabi. Kuala Lumpur: Dewan Bahasa dan Pustaka.

Barker 2003. Cultural Studies: Theory and Practice, London: Sage.

Grossberg 1993. 'The Formation of Cultural Studies: An American in Bermingham', dlm. Blundell, Vanda, Shepherd, John dan Taylor, Ian, Relocating Cultural Studies: Developments in Theory and Research, London: Routledge.

Imtiyaz Yusuf 2006. "The Ethno-Relegious Dimension of the Conflict in Southern Thailand," dlm. Imtiyaz Yusuf dan Lars Peter Schmidt, Understanding Conflict and Approaching Peace in Southern Thailand. Bangkok: Konrad-Adenauer-Stiftung.

Office For National Statistics 2002. Tua Chiwad ti samkan tang dan prachakorn lae ti u asai jak komun krongkan sammano prachakorn lae keha poso 25232533 lae 2543. Bangkok: Jabatan Statistik Negara, Jabatan Menteri Teknologi dan Komunikasi.

Kamus Dewan Edisi Ketiga 1998. Kuala Lumpur: Dewan Bahasa dan Pustaka.

Kavanagh 1991. "Ideology," dlm. Lentriechia, Frank dan Thomas McLanghin, Critical Terms for Literary Study. London: The University of Chicago.

Jelani Harun, "Permasalahan Sosiobudaya Masyarakat Melayu di Singapura dan Pulau Pinang: Suatu Penelitian Terhadap Kilat Senja dan Aci Patmabi" in Prosiding Persidangan Serantau Kesusasteraan Melayu Malaysia-Singapura dalam Dimensi Pasca'65, 2013.

Longman Encyclopedia 1987. London: Longman.

Mana Sikana 2007. Teori Sastera Kontemporari. Petaling Jaya: Pustaka Karya.

McCargo, "Introduction: Rethinking Thailand's Southern Violence," in Journal of Critical Asian Studies, 38:1 (2006).

Montri Sriyong 2012. Rusni. Bangkok: Samanchon.

Said 2009.Budaya dan Imperialisme. Kuala Lumpur: Institut Terjemahan Negara Malaysia.

Shahnon Ahmad 1980. Gubahan Novel. Kuala Lumpur: Dewan Bahasa dan Pustaka. 